\title{
Sustainable analysis of integrated cajuput oil business development as a sustainable forestry multi-business at PT Inhutani I
}

Titik Ermawati, Lailan Syaufina, Hariyadi

Natural Resources and Environmental Management Study Program, Graduate School, IPB University, Bogor, Indonesia

\section{Article Info:}

Received: 22 - 09 - 2021

Accepted: 13 - 12 - 2021

Keywords:

Cajuput, feasibility analysis, sustainability analysis

Corresponding Author:

Titik Ermawati

Natural Resources and

Environmental Management

Study Program, Graduate

School, IPB University;

Email:

titik.ermawatititik@apps.ipb.ac.i d

How to cite (CSE Style $8^{\text {th }}$ Edition):

Ermawati T, Syaufina L, Hariyadi. 2021. Sustainable analysis of integrated cajuput oil business development as a sustainable forestry multi-business at PT Inhutani I. JPSL 11(4): 631-637. http://dx.doi.org/10.29244/jpsl.11.4.631-637.

\section{INTRODUCTION}

The increasing population will increase the amount of food, shelter, and energy needs. Prayogo et al., (2000) stated that this was one of the drivers of land-use change from forest areas to agricultural land, settlements, and plantations. Based on the Ministry of Environment and Forestry (2019), deforestation in Indonesia in 2017-2018 reached 0.49 million ha. The most considerable deforestation occurred in secondary forest cover, which was 351.1 thousand ha $(71.2 \%)$, followed by primary forest at 72.1 thousand ha (14.6\%) and plantation forest at 70.2 thousand ha (14.2\%). Sulawesi Island ranks fourth in deforestation after Kalimantan, Sumatera, and Papua. Deforestation in Sulawesi Island reached 14.6 thousand ha, covering the provinces of Southeast Sulawesi (8.39 thousand ha), Central Sulawesi (2.88 thousand ha), and South Sulawesi (1.85 thousand ha) as the top three areas of highest deforestation.

Based on Austin et al., (2019), the causes of deforestation in Indonesia are categorized based on 12 types of activities. Activities that cause deforestation include Oil Palm Plantation, Timber Plantation, Other largescale plantations, Grassland, Small-scale agriculture, small-scale mixed plantations, small-scale oil palm 
plantations, mining, fish pong, logging road, secondary forest, and others. Since the period 2011-2016, the three major categories of contributors to deforestation in Indonesia are Oil Palm Plantation (23\%), Timber Plantation (14\%), and Large-Scale Plantation (7\%). Rosenbaum et al., (2020) noted that the causes of deforestation in Sulawesi have the same pattern, including Logging, Oil Palm Plantation, Mining, and Corruption. Deforestation impacts climate change, increased weather, the occurrence of forest fires, the increasing incidence of natural disasters, and threats to biodiversity. Other impacts are decreasing habitat quality to species extinction.

Furthermore, deforestation causes a change in the condition of stands or treads in a forest (forest degradation) that negatively impacts (Lund, 2009). The degradation that occurs will reduce species composition, biodiversity, and forest productivity (FAO, 2010) and decline land productivity in the future (Oldeman, 1994). Land degradation due to deforestation will indirectly impact the occurrence of community poverty in and around the forest (Lamb et al., 2005).

Cajuput is one type of plant suitable for the Rehabilitation of forests and land because it can live on marginal lands (Rimbawanto et al., 2017). In addition to providing ecological benefits, this type of plant produces leaves that can be harvested and distilled to produce Cajuput oil. In marginal areas bordering the communities around the forest, Melaleuca Cajuput planting can provide employment and improve the welfare of the community around the forest, so it is suitable to be developed to open jobs and reduce poverty. Indonesian people have long known cajuput oil and use it to overcome mild health problems (Doran et al., 1998). Sudradjat (2020) further explained the benefits of cajuput oil for treating the respiratory tract, antiinflammatory, anti-microbial, antiviral, antiplastic, anti-cancer, analgesic, sedative, and hypertension. In general, Indonesian people provide cajuput oil to help health in their households. The need for cajuput oil is increasing concerning the increasing population and growing variety of cajuput oil utilization. Due to the supply-demand chain gap, cajuput oil businesses import cajuput oil to meet the needs of the packaging industry. This step resulted in two losses. Namely, consumers of cajuput oil did not get pure cajuput oil, and state foreign exchange was forced to be used to import raw materials that could be produced alone (Rimbawanto et al., 2018).

In Indonesia, cajuput oil is a product of Non-Timber Forest Products (NTFP), as one of the forest resources that have a comparative advantage and most intersects with the community around the forest, as well as one of Indonesia's mainstay essential oils, has a relatively stable price, is very prospective to develop, and is easy to cultivate on critical land. Currently, NTFP is proven to impact increasing the income of the community around the forest and make a meaningful contribution to the addition of state foreign exchange. For that, it is necessary to increase the production of cajuput oil through intensification, namely the breeding of cajuput plants so that superior seeds are produced and extensive (expansion of cajuput gardens). Whitewood breeding since 1995 has produced superior seeds of cajuput plants with high oil yields of $1.2 \%$ or more and better levels of 1.8-cineole. For comparison, oil yields from cajuput gardens in Java Island range from 0.60$1.00 \%$, while in Buru Island and Seram Island average only $0.6 \%$ (Rimbawanto et al., 2017), and pilot trials of small-scale M. Cajuput development projects with superior seedlings for farmers groups in Kampung Rimbajaya, East Biak District high yield (1.3\%) (Rimbawanto et al., 2018).

In the framework of sustainability, Cajuput business must make changes (change) and innovation (Innovation), efforts to integrate environmental interests, namely social, economic, and ecological, in a balanced manner. This is done considering that many business fields have failed because they are done without including sustainability calculations so that the impact is profound on their business. Feasibility and sustainability analysis of the plant-scale whitewood planting business. At its core, it is to make changes and innovations that characterize novelty by developing a model of integration of cajuput business based on sustainability principles. This model was developed by including environmental protection and preservation variables that are essential in environmental science studies, based on the balance of the three pillars of the environment, namely social, economic, and ecological. Sustainable development is an important issue and must be implemented in a balanced, precise, and tangible manner that includes sustainability and human 632 
happiness and sustainability in glorifying nature and all His creation. Three human activities that act as caliphs of Allah, which are often questioned, namely: (1) to what extent conservation; (2) to what extent applying deep ecology or ecosophy; and (3) to what extent to the economic development of society appropriately and correctly. All three are slices between two factors that play a role where each has detailed parameters (Alikodra, 2020).

\section{METHOD}

\section{Study Area and Period}

The research was conducted from January to May 2021. The study area covers PT INHUTANI I Gowa, South Sulawesi Province.

\section{Data Analysis}

In accordance with the principles of environmental science that integrates socio-cultural and environmental elements. Sustainability analysis on the basis of the cobweb model can be determined through four stages of activities: setting parameters and sub-parameters that determine the cobweb model, determining the magnitude of qualitative scale, developing models, and conducting development analysis (Bell and Morse, 2003).

1. Establishing parameters and sub-parameters consists of legal aspects, socio-economic and cultural aspects, market aspects, human resource management aspects, risk aspects, technical aspects, and financial aspects. Aspects and financial aspects.

2. Set the quantitative value amount of research results for each parameter. In accordance with its character, it is then established as the basis of qualitative value (very low, low, medium, good, and very good).

3. Constructing a cobweb model is based on three criteria for each parameter. The magnitude of the qualitative scale value for each parameter is connected, thus forming a spider's nest model. In the cajuput oil business research in Gowa, there are seven aspects that will be improved sustainability on the scale of production capacity to meet the needs of the domestic market.

a. Agency Survey, interview of social, economic, and cultural aspects of society.

b. Respondents included related parties such as officials of the Gowa District Industry and Trade Office, Village Heads in plan forest management unit Gowa work areas, as well as the general public.

c. Secondary Data Collection (soil, climate, demographics, soil type, supporting company data) Soil type classification data for the suitability of Cajuput plant land in the planting plan area or plants d. Market Feasibility, carried out in 6 stages, namely: (1) Identification of Cajuput oil marketing problems; (2) Draw up a market plan; (3) Data collection; (4) Analysis of information; (5) Analysis of findings; (6) Decision making of market aspects.

\section{RESULTS AND DISCUSSIONS}

Based on the results of analysis and discussion of seven aspects that play a role in the development and development of cajuput oil business, namely: legal aspects; socio-cultural-economic community; human resources; business risk; market; and financial aspects (NPV, BC Ratio, IRR) Thompson and George (2009). It can be known that cajuput oil-PT Inhutani I business is declared feasible. Business feasibility is analyzed on the basis of achieving the objective of supply to meet the needs (demand) of the domestic market.

The cobweb model is built on the fact each parameter is as follows: Feasibility of the legal aspects of each aspect with each sub-aspect: Conformity of Planting Plan with Map of Forest Area and Water Conservation of South Sulawesi Province, RTRW of South Sulawesi Province and RTRW regency Including feasible, because it is in a fixed production forest area and limited production forest (HPT). The suitability of the location of the establishment of the processing plant in Block IV Plot 6 with RTRW of South Sulawesi Province and RTRW 
of Gowa Regency is appropriate. The feasibility of the aspect socio-economic and cultural aspects from each sub-aspect is as follows: Public perception is still low related to the introduction of cajuput oil development plan in Plan Forest Manajemen Unit Gowa working area so that it requires more intensive socialization activities. The level of community acceptance of the cajuput plant development plan is quite high.

However, the community still wants to be involved in planting activity and keep her herding her livestock in forest areas. Therefore, in overcoming the desire for M. Cajuputi cultivation involvement, it is necessary to use farmers as labour in planting and harvesting activities M. Cajuputi leaves. In overcoming grazed livestock, it is necessary to approach and get consensus so as not to graze young cajuput plants or do freshening with fence plants. The level of cultural conformity of cajuput planting culture is still not appropriate because the community does not know the plants or cultivation and harvest the leaves of cajuput plants. Based on the conditions of the suitability of cajuput cultivation requires training efforts on cajuput plant cultivation and harvesting of cajuput leaves for the community that will be involved in cajuput planting activities. The labour absorbtion rate from the 5200 hectares cajuput plant planting plan integrated with the cajuput oil processing plant is estimated to be high enough to be able to absorb labour both locally, Gowa Regency level and South Sulawesi Province level.

Feasibility of the market aspect of each sub-aspect is as follows: The market segment of cajuput oil products is prioritized in market segmentation with Super Quality Class with the target market is the pharmaceutical industry and other industries to fill the shortage of cajuput oil suppliers from within the country. The suitability of the benefit offering to be offered with the wishes of consumers is appropriate, especially in ensuring the accuracy of the quantity and quality desired by consumers through the integrated processing of cajuput oil between the garden and the cajuput oil processing plant. The existence of network marketing through a holding company, Perhutani General Company, which already has a marketing network, can be utilized to increase marketing efficiency.

\section{Feasibility of Aspects of Management and Human Resources}

The results of Feasibility of Aspects of Management and Human Resources: Identifying the need for expertise in the development of cajuput oil integrated between whitewood plant cultivation and cajuput oil plant include expertise in cajuput plant cultivation, harvesting, and transportation of cajuput leaves, cajuput oil processing, and marketing expertise. The result of environmental identification of similar companies is producers of cajuput oil, so considering that the company is a new player in this commodity, the initial position to be determined to fill market share that has not been met by the local market which at the moment is now filled by Eucalyptus oil imports, especially to supply the pharmaceutical industry in South Sulawesi province and East Indonesia. But in the future, it must try to take a position as a substitute for imported goods by continuing to increase the amount of production and quality that meets SNI standards. The approach that companies can use is the development of common strategies and the use of portfolio approaches. Based on the possibility of establishing a cajuput oil factory in the future to fulfill the three blocks of the development plan, namely Block IV, Block III, and Block V, the factory has its own organization responsible to the Manager of INHUTANI I, with an organizational structure that is integrated between the cajuput plantation/forest and the cajuput oil processing plant which is directly responsible to the manager.

From the aspect of risk management in the development of cajuput oil is faced with: 1) pure risk (pure risk) consists of three types of risk pure risk consists of three risks, namely physical asset risk, team member risk, and legal risk; 2) Speculative risk is grouped into four types of risk: market risk, credit risk, liquidity risk, and operational risk. These risks can be addressed by using risk management to minimize risk, shift risk, control risk, and risk funding.

The feasibility of the aspect of the technical aspects of each sub-aspect is as follows: From the technical silviculture development plan for cajuput oil business covering an area of 5200 ha is feasible, which includes Block IV area of 2000 ha, Block III covering an area of 1200 ha and Block V covering an area of 2000 ha. 
The engineering of the cajuput oil processing plant is well deserved from the aspect of location in the forest area with a distillation system with steam. The feasibility of the financial aspects of each sub-aspect is as follows: Cajuput oil business with an area of 5200 ha requires an investment of IDR 2153925 000, consisting of forest development investment of IDR 917597000 and factory development investment of IDR 1236328 000 Forest development consists of seedling development which includes the construction of seedlings amounting to IDR 305407 000, nursery equipment amounting to IDR 52190 000, and road infrastructure facilities amounting to IDR 560000000.

NPV, BC Ratio, IRR, and payback period are obtained as follows: Present Net Value (NPV) of IDR 950734956 062, with a discounted interest rate of 12\%, indicates that the cajuput oil industry business will get a net profit of IDR 7076409779 281. The BC Ratio of 12.56 shows that the business of the cajuput oil industry by utilizing superior seed technology is commercially viable. An Interest Rate of Return (IRR) of $55 \%$ indicates that the rate of return on investment is higher than the capital interest rate (12\%). Payback Period in the $5^{\text {th }}$ year of 4 months indicates that within 5 years, the investment can be returned from receipt of business.

Table 1 Sustainability conditions of cajuput oil development

\begin{tabular}{clcc}
\hline N & \multicolumn{1}{c}{ Aspect } & $\begin{array}{c}\text { Current Sustainability } \\
\text { Conditions }\end{array}$ & $\begin{array}{c}\text { Sustainability } \\
\text { Development Conditions }\end{array}$ \\
\hline 1 & Legal Aspects & 5 & 5 \\
2 & Socio-economic and cultural Aspect & 3.5 & 5 \\
3 & Market Aspect & 5 & 5 \\
\multicolumn{2}{l}{ Aspects of Management and Human } & 4 & 5 \\
4 & Resources & 5 & 5 \\
5 & Technical aspects & 3 & 5 \\
6 & Aspects of risk management & 5 & 5 \\
7 & financial aspects & & \\
\hline
\end{tabular}

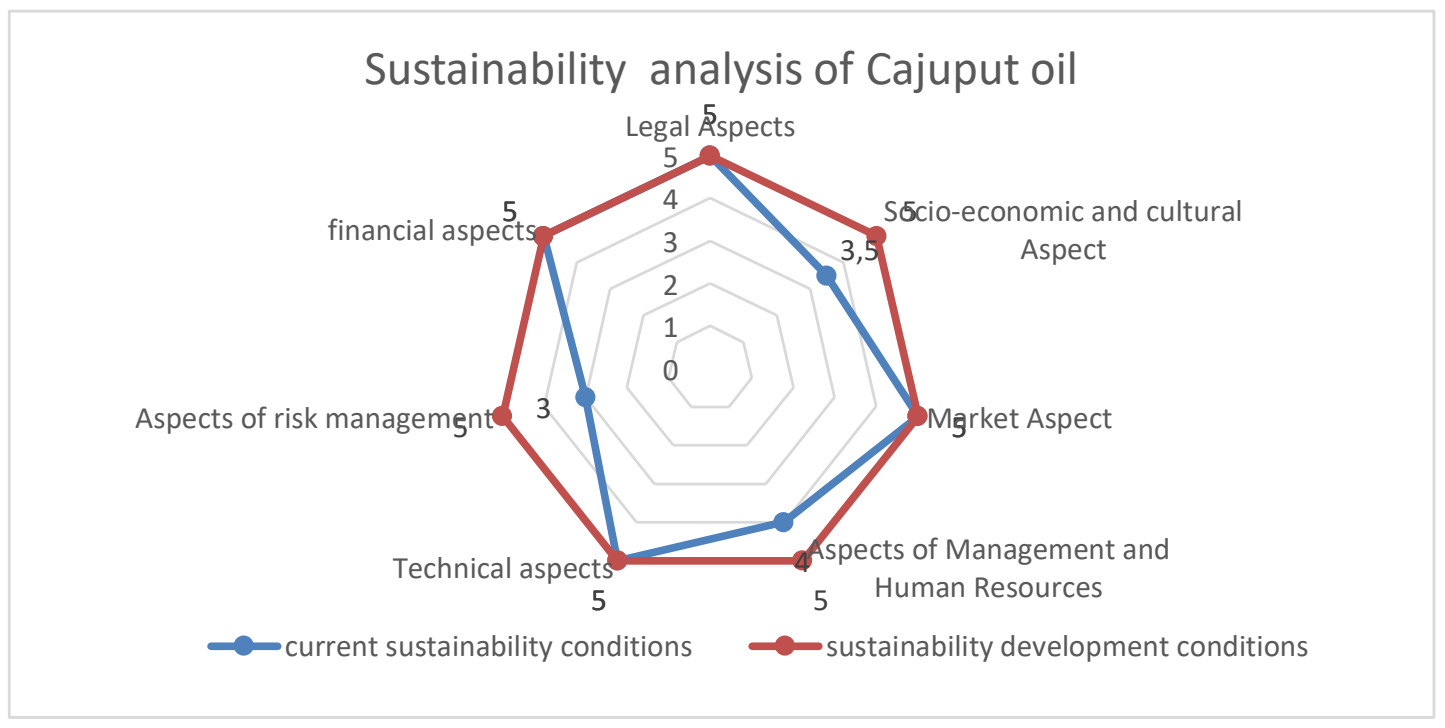

Figure 1 Cajuput oil business development Spider's Nest Model

The webbed model of the sustainability analysis of the Cajuput oil business of INHUTANI I, South Sulawesi, shows the current condition of Cajuput oil's business management capacity (Table 1 and Figure 1). On the basis of the current conditions in accordance with the capacity scale of each aspect, development is needed towards a scale- 5 by increasing management capacity. The company must professionally and perform development (change and innovation) by means of refinement to increase the weak elements. To achieve the 
feasibility of sustainable cajuput, oil businesses must be developed integrated management patterns, look integrally and holistically at all the factors involved, and increase their capacity (Assauri, 2016).

The pattern of management novelty must also consider the condition of global warming and the development of the covid-19 pandemic virus that can potentially destroy the economic-economic aspects of communities and countries. The Indonesian government already has a nature conservation strategy that is the basis for developing sustainability issues declared. In Bali, in 1982, the goal was to protect, preserve, and utilize SDA wisely and sustainably. For its implementation, the President of the Republic of Indonesia issued Presidential Regulation No. 59 of 2017 on the Implementation of the Achievement of sustainable development goals. But many face obstacles and obstacles in its implementation, mainly due to weak institutional capacity support. Given the importance of developing human resources capacity, organization, technical instructions, and clarity of working mechanisms, therefore the capacity of cajuput oil Business management institutions needs to be prioritized to be improved, especially in the face of increasingly complex problems, such as natural disasters, climate change, ecotourism development, and environmental interpretation, as well as labour and poverty issues.

\section{Development Strategy}

The development of each on the cobweb model towards a good scale, as a business development strategy. It was built on constructive assumptions such as those previously stated on seven aspects of the business environment. Through the concept of sustainable development approach, in accordance with the goals and programs of the SDGs 2015-2030, it is essentially achieving the goal of people's happiness. For this reason, it is necessary to change the paradigm and mindset of human resources and business behavior in accordance with the philosophy of environmental sustainability (Alikodra, 2020).

In the short-term implementation, gradually and continuously improve the capacity of leadership, organization, and work mechanism in the unity of business units. Real business and activities are needed by not using the principle of business as usual to achieve the goals and objectives of a sustainable cajuput oil business. The basic principles include biodiversity sustainability, employment, reducing poverty, and energy adequacy. This strategy or tactic is to achieve the people's happiness index following the basic principle of sustainable development, which is to integrate socio-cultural, economic, and environmental balance.

The strategy is to increase business capacity in real terms by increasing weak parameters on all aspects of the cobweb model, including Increased synchronization of the role of the cajuput oil business with the community and the surrounding environment in disaster adaptation and mitigation, increased food sources, public health, renewable energy sources (solar, wind, steam), and restoration of damaged land. They are improving marketing aspects through promotion in overseas market segments by improving quality and quality, continuity of products and packaging. Intensification of production exhibitions abroad through the role of embassies of friendly countries. They were improving HR leadership by developing higher education opportunities in various fields of sustainable business, training, internships, and participating in international meetings in their fields. Open to change and innovation continuously, given the increasingly uncertain trade climate and stability of the world economy, and openness in corporate auditing and HR recruitment.

\section{CONCLUSIONS}

On the basis of an analysis of seven aspects that determine the feasibility of the company, namely legal aspects, socio-cultural-economic community, human resources, business risk, market, and financial aspects (NPV, BC Ratio, IRR), then the business of cajuput oil PT INHUTANI is a category worthy of being developed. In accordance with the mapping of the cobweb model in the current conditions, for the sustainability of cajuput oil business needs to increase the capacity of socio-cultural-economic aspects of society, human resources, and business risk to a value of five (very good). As for the legal, technical, market and financial aspects (NPV, BC Ratio, IRR) already included in the category of value five (very good), so it 
must be maintained. For the long term, cajuput oil entrepreneurs should develop sustainability optimally, namely not only meeting the needs of the domestic cajuput oil market but also to meet export market targets, so that a long-term strategy is needed, namely increasing the capacity of cajuput oil business including increasing the capacity of our leadership, organization, and the capacity of rules/mechanisms of work. In the short term, the cajuput oil business in order to increase public understanding of cajuput oil business, provision of employment and reduce poverty of rural communities around cajuput oil activities/companies, so as to build active participation of the community towards sustainable cajuput oil business.

\section{ACKNOWLEDGMENT}

The author would like to thank PT Inhutani I Gowa, South Sulawesi, for the support and financial assistance so that this research can be carried out properly.

\section{REFERENCES}

[FAO] Food and Agriculture Organization. 2010. Global Forest Resources Assessment 2010 Main Report. Rome (RO): FAO Forestry Paper

Alikodra HS. 2020. Era Baru Konservasi Sumberdaya Alam dan Lingkungan Membumikan Ekosofi Bagi Keberlanjutan Umat. Bogor (ID): IPB Press.

Assauri S. 2016. Strategic Management. Sustainable Competitive Advantages. Ed $2^{\text {nd }}$. Jakarta (ID): PT Rajawali Press.

Austin KG, Schwantes A, Gu Y, Kasibhatla PS. 2019. What causes deforestation in Indonesia?. Environmental Research Letters. 14(024007): 1-9.

Bell S, Morse S. 2003. Measuring Sustainability Learning by Doing. London (GB): Earthscan Publications Ltd.

Doran JC, Rimbawanto A, Gunn BV, Nirsatmanto A. 1998. Breeding plan for Melaleuca Cajuputi subsp. cajuputi in Indonesia. Yogyakarta (ID): Forest Tree Improvement Research and Development Institute.

Lamb D, Erskine PD, Parrota JA. 2005. Restoration of degraded tropical forest landscapes. Science. 310 (5754): 1628-1632.

Lund HG. 2009. What is a Degraded Forest?. Gainesville (US): Forest Information Services.

Ministry of Environment and Forestry. 2019. Ministry of Environment and Forestry Performance Report 2019. Jakarta (ID): Ministry of Environment and Forestry.

Oldeman LR. 1994. The global extent of soil degradation. In: Greenland DJ, Szabolcs I, editor. Soil Resilience and Sustainable Landuse. Wallingford (GB): CAB International.

Prayogo C, Hairiah K, van Noordwijk M. 2000. Kuantifikasi modal dan distribusi karbon dalam system tebang bakar pada lahan berlereng di Rantau Pandan, Jambi. Agrivita J. 22(2): 91-102.

Rimbawanto A, Kartikawati NK, Prastyono. 2017. Minyak Kayu Putih dari Tanaman Asli Indonesia Untuk dan Kebijakan Pertanian. Yogjakarta (ID): Kaliwangi (Anggota IKAPI).

Rimbawanto A, Prastyono, Kartikawati NK, Sumardi. 2018. Kebun kayuputih skala kecil untuk memenuhi kebutuhan minyak kayuputih dalam negeri dan mengurangi impor minyak substitusi. Seminar Nasional Silvikultur IV; 2018 Aug 8; Kendari, Indonesia. Kendari (ID): Pusat Pengkajian Perubahan Iklim Universitas Mulawarman.

Rosenbaum B, Brien TGO, Supriatna J. 2020. Population densities of Sulawesi crested black macaques (Macaca nigra) on Bacan and Sulawesi, Indonesia: Effects of habitat disturbance and hunting. American Journal of Primatology. 44(2): 89-106.

Sudradjat S. 2020. Minyak kayu putih obat alami dengan banyak khasiat: tinjauan sistematik. JKdoktMeditek. 26(2): 51-59.

Thompson D, George B. 2009. Financial and economic evaluation of agroforestry. In: Nuberg I, George B, Reid R, editor. Agroforestry for Natural Resource Management. Collingwood (AU): CSIRO Publishing. 